\title{
足関節外果部難治性潰瘍の治療
}

\author{
新日本製鉄八幡製鉄所病院形成外科 \\ 碓 井 良 弘・尾 崎 正 美 \\ 古田文 隆·德重広幸
}

\section{Treatment of Lateral Malleolar Ulcers.}

by

\section{Yoshihiro Usui, Masami Ozaki, Fumitaka Furuta and Hiroyuki Tokushige}

Nippon Steel Corporation Yawata Works Hospital Department of Plastic and Reconstructive Surgery to heal.

Ulcers often develop on the lateral malleolar area in aged patients and are difficult lows:

We describe a simple surgical method to treat the ulcer. This procedure is as fol-

1. Resection of long and short fibular tendons.

2. The cortical bone of the lateral malleolus is shaved.

3. Split-thickness skin grafting using a scalp skin.

4. Immobization of the ankle joint by plaster cast.

\section{はじめに}

高令者の足関節外果部に生じた潰揚は，たとえ小さ いものでも, 治療が難渋している症例を見ることは稀 ではない，近年，潰瘍の治療に用いられる皮弁の進歩 は目を見張るものがあるが，そのような手術法は相当 なトレーニングを積んだ専門家でなければ容易に用い ることが出来るものではない，また，患者は高令者で, 循環障害などの合併症をもっていることも多く，その ような方法が適応とならないことも少くない. 潰瘍が それほど大きくない場合には，主治医である外科医や 整形外科医が自分で治そうとするのが普通であり，小 さな侵襲で，確実に治す方法が求められる．これまで そのような症例の治療を度々経験してきたので, 最近 経験した 2 症例を示して,われわれが通常用いている 方法について述べる.

症例

症例 1,73 才, 男
主訴 : 左第 $3,4,5$ 趾壊死, 左足関節外果部難治 性潰瘍.

現症歴: 平成 2 年 11 月 26 日, 左第 $3,4,5$ 趾の 変形に対して手術を受けたところ, 同部が壊死となっ た. 左下肢の循環障害が強く疑われ, 血管外科を紹介 受診し, 左下肢閉塞性動脈硬化症の診断のもとに, 平 成 3 年 3 月 5 日, 左腋高動脈一左大腿動脈のバイパス 手術を受けた。術後は循環障害は改善されたが, 術後 臥床中に左足関節外果部に裖創を作った，その治療の ために当科受診となった.

合併症：陳旧性心筋梗塞, 左下肢閉塞性動脈硬化症. 治療: 平成 3 年 4 月 26 日, 左第 $3,4,5$ 趾壊死. 左足関節外果部裖創に対して手術を行った. 左第 3 , 4, 5 趾の趾骨は露出して, 壊死となっていたので, これを切降. 短縮し, 断端を軟部組織で被覆して, そ の上に頭皮からの分層植皮を行った．左足関節外果部 裖創に対しては, 外果部の骨皮質を剥削して, 同部に 頭皮からの分層植皮を行ったが，これまでの経験から， 同部の後方にある長, 短腓骨筋腱は筋の等尺性収縮運 
動による腱緊張の変化のために，植皮の生着を妨げ， また，その感染も併せて植皮の生着を障害すると考え たので，これを切除した．術後はギプスシーネを用い て足関節を固定した，植皮はよく生着し，創は順調に 治瘉へと向かったキギプス固定は植皮の生着が安定す るまで 20 日間行った，創が治癒したとき，患者はそ れまでの半年間, ベット上安静と車椅子生活の繰り返 しであったため, 起立, 歩行不能となっていたが, リ ハビリテーションを行った結果, 約 1 カ月後に歩行出 来るようになった，長，短腓骨筋腱切除の影響は見ら れなかった（写真 1 - a , b , c )

症例 2,79 才, 男

主訴 : 右足関節外果難治性潰瘍.

現症歴: 平成 2 年 9 月, 右足関節外果部軟部腫瘍の 摘出術を受けた。 術後, 同部は感染を起こし, 潰瘍と なった。その後, 潰瘍に対して 5 回の手術を受けたが 治らないので, 平成 3 年 6 月 22 日, 当科入院となっ た。

\section{合併症：貧血（RBC 382 万， Hb $12.1 \mathrm{~g} / \mathrm{dl}$ )}

治療: 平成 3 年 6 月 22 日, 右足関節外果部潰痬に 対して手術を行った. 手術は外果部の骨皮質を剥削し て，その上に頭皮からの分層植皮を行ったのであるが， 前の症例と同じ理由で, 長, 短腓骨筋腱も切除した。 術後はギプスシーネを用いて足関節を固定した。

植皮は生着したかに見えたが, 一部生着不良のとこ ろがあって, そこから生着不良部が拡大していった。 そこで, 平成 3 年 7 月 16 日, 再手術を行った。手術 は双茎皮弁で㵅瘍部を被覆し, 皮弁の恵皮部を頭皮か らの分層植皮で被覆した，術後はギプスシーネを用い て足関節を固定した，術後は皮弁，植皮ともに問題な く, 創は順調に治癒へ向かった，創治癒後の患者の歩 行は術前となんら変りはなく, 長, 短腓骨筋腱切除の 影響は無視出来た。 (写真 $2-a, b, c, d$ )

\section{考}

察

足関節外果部は臥床時に足の下になるため, 高令者 では容易に潰瘍を作り, それが難治性となって, 数回 の手術を受けたにもかかわらずそれが総て失敗に䚻し, 治療に難踨しているものをしばしば見かける，潰瘍部 には骨や腱が露出しているため, 通常の遊離植皮は適 応にはならず，縫縮も困難なことが多い。

このようなものに対しては皮弁による創閉鎖が適応

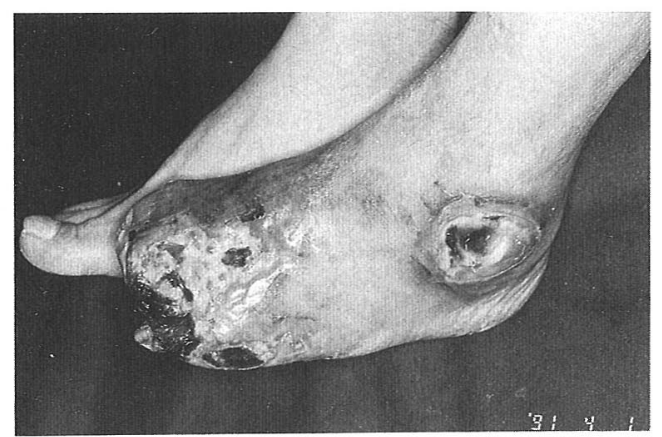

a

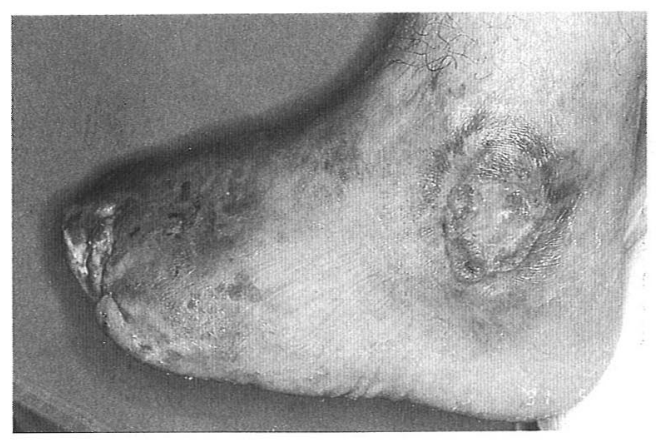

b

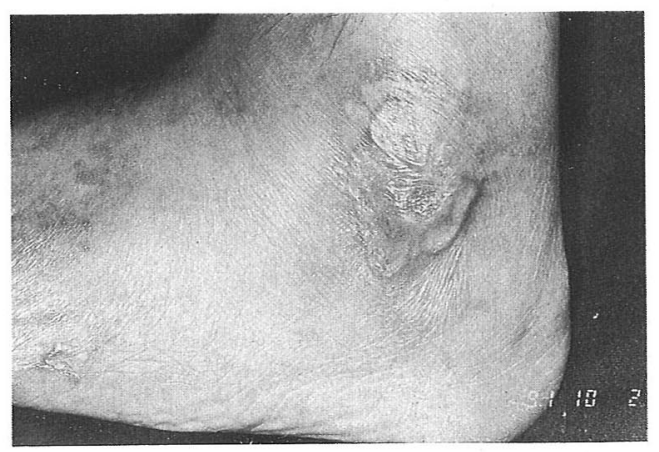

c

写真 1 a 初診時

左足関節外果部に裖創があり，壊死組織 が付着している. 第 $3 ， 4 ， 5$ 趾は趾骨 が露出した潰瘍となっている.

b 術後 35 日

植皮はよく生着し創はほほ治癒している.

C 術後 4 力月 


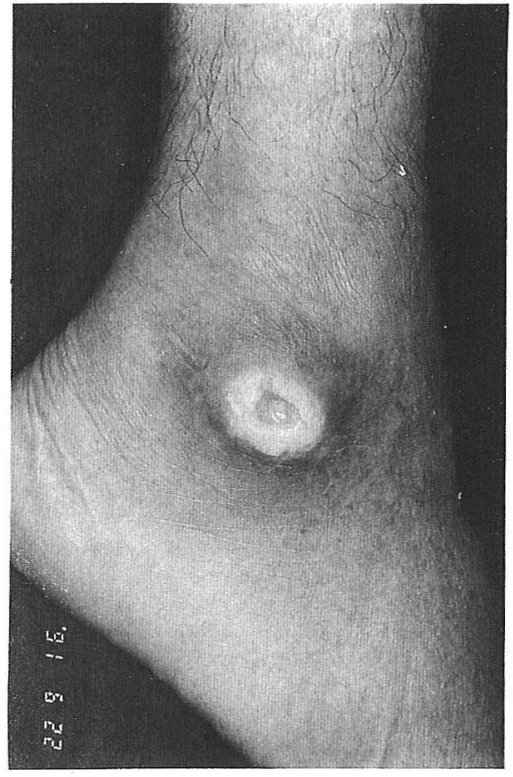

a

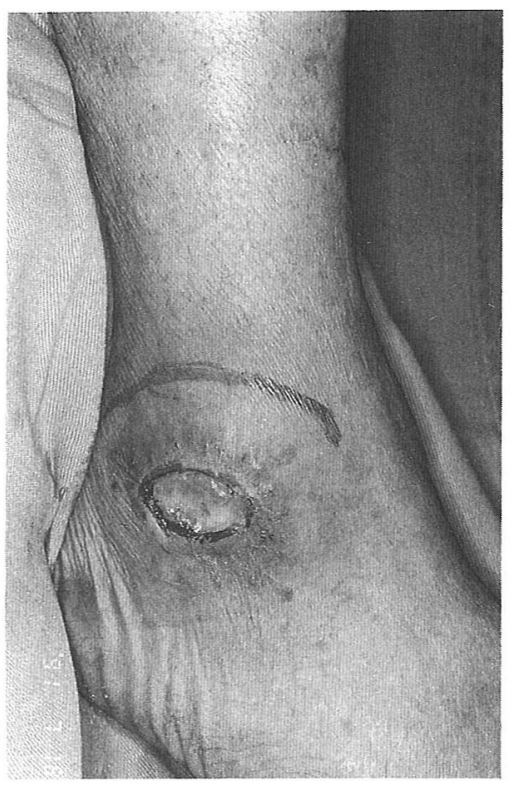

c

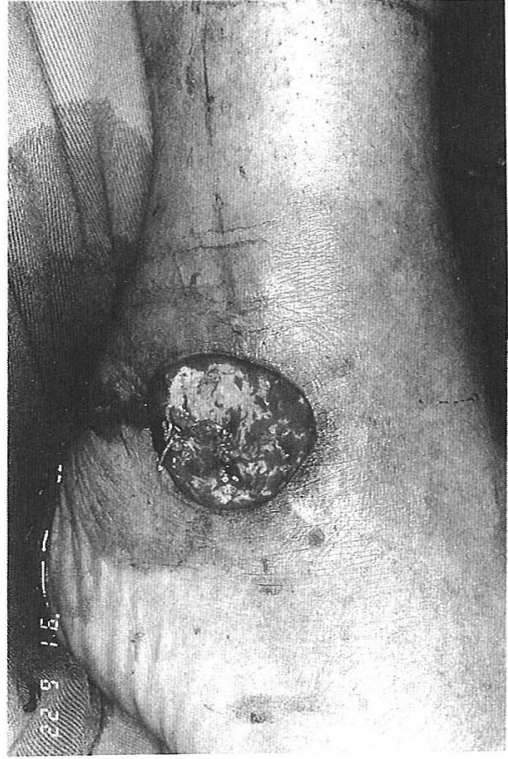

b

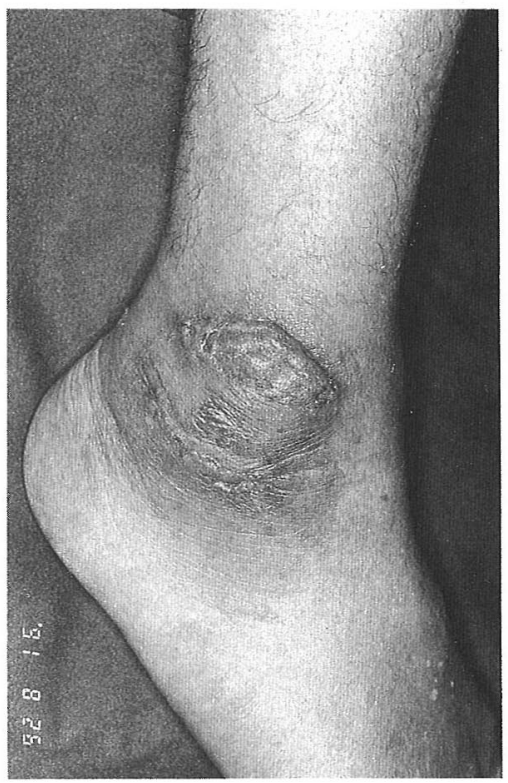

d

写真 2 a 初診時

b 初回手術 : Bursa を完全に切除し, 外果 骨皮質を剥削したところ。

c 2 回目の手術のデザイン

d 術後41日, 創は治痛している. 
となる。

足関節部に用いられる皮弁は, 古くは cross-leg flap から, 近年は dorsalis pedis flap ${ }^{4)}$, peroneal flap ${ }^{5) 6)}$, posterior calf fasciocutaneous flap ${ }^{2)}$, lateral supramalleolar flap $^{3)}$, reverse-flow lateral supramalleolar flap ${ }^{1)}$, などが報告され, その他, 種々の free flapが用いられる.これらの方 法は熟練した形成外科医か, microsurgery が出来 る整形外科医などの限られた外科医だけが用いること が出来る高度の技術を要する方法であり，これらの患 者の主治医が手軽に用いることが出来るものではない. また，このような患者は高令者で, 動脈硬化をはじめ, 種々の合併症をもっているため, これらの方法が適応 とならないことも少なくない，そこで，簡単な手術で 確実に治せる方法が求められるわけである.

われわれは，ここに述べた方法をまず試み，多くは 創の治癒に成功した，足関節外果部は骨皮質を剥削す れば海綿骨が出てくる，その上には植皮が可能なはず である.しかし，往々にしてその植皮が失敗するのは 何が原因であろうか？ それは多分術後の局所の安静 が充分でなかったためと, 感染が原因であろうと思わ れる、だから，術後はギプスシーネを用いて足関節を 強固に固定してみたが，それでも失敗することがあっ た。

潰瘍部の後方にある長，短腓骨筋腱は往々にして露 出しており，感染が波及している．腱が感染を受ける と極めて難治性であり，この感染が植皮生着を妨げる 原因の 1 つと考えられる。また，足関節を固定してい るとはいえ, 筋の等尺性収縮は腱の緊張をたえず変化 させて局所の安静を妨げ，植皮生着の障害となってい ることが考えられる. 同様の現象は大腿後面から膝窩 部に植皮を行ったとき，大腿二頭筋のれん縮のため， 腱に沿って植皮の生着が障害されることに見ることが 出来る，そこで，この腱を切除することにしたのであ る.この腱を切除するようになって創治癒の成功率は 向上したように思われる. 皮膚の欠損が外果部に限局
しているものでは，まずこの方法で創治癒に成功する のではないかと考えている. 高令者の中には足の血行 が極めて悪い場合があり，総てが成功するとは云えな い面もあるが，そのような症例には他の方法でもうま くいかないのであり, 治療の限界と云うべきものであ ろう。

長, 短腓骨筋腱を切除したための障害は無視出来る ようである. 潰瘍の治療のために長期間車椅子生活を 余儀なくされ，そのために歩行困難となっていた患者 もあったが, この腱を切除して創治癒が得られた後, リハビリテーションによって歩行可能となった例もみ られた。

$$
\text { ま と め }
$$

高令者に生じた足関節外果部の難治性潰瘍に対する 簡単な手術法について述べた。 その方法は, 露出した 外果部の骨皮質を剥削して, 頭皮からの分層植皮を行 うのであるが, その際, 長, 短腓骨筋腱を切除する. 術後は足関節をギプスシーネで固定する。この方法に よって治瘉が得られないときには，双茎皮弁で潰瘍部 を覆い, その恵皮部に頭皮からの分層植皮を行う。こ れらの方法によって治療した 2 例を示した.

\section{文献}

1) 秋元正字他: Lateral Supramalleolar Flap の経験, 日形会誌, 9, nov. 5, 460, 1989.

2) 佐藤兼重他: Posterior Calf Fasciocutancus Flap の 解剖学的臨床的検討, 日形会誌, 5, nov. 3, 262, 1985.

3) Masquelet, A.C. et al.: The Lateral Supramalleolar Flap, Plasrt. \& Reconstr. Surg., 81, nov. 1, 74, 1988.

4) McCraw, M.J et al.: The Dorsalis Pedis Arterialized Flap, Plast. \& Reconstr. Surg. 55, nov. 2, 177, 1975.

5) Yosimura, M. et al.: Peroneal Flap for Reconstruction in the Extremity: Preliminary Report, Plast. \& Reconstr. Surg. 74, nov. 3, 402, 1984.

6) 吉村光生他 : Peroneal Flap による四肢再建, 形成外 科, 27 , nov. $5,396,1984$. 